\title{
PREPORUKE ZA POBOLJŠANJE HRVATSKOG PRAVNOG OKVIRA I MJERA ZA SUZBIJANJE I PREVENCIJU TRGOVANJA LJUDIMA
}

Izv. prof. dr. sc. Lana Ofak*

Izv. prof. dr. sc. Maja Munivrana Vajda**
UDK: $343.343 .6(497.5)$

$343.431(497.5)$

$341.231 .14: 343.431$

DOI: 10.3935/zpfz.69.1.03

Izvorni znanstveni rad

Primljeno: rujan 2018.

Autorice u radu analiziraju postojeći pravni i institucionalni okvir za suzbijanje trgovanja ljudima u Republici Hrvatskoj. Iako je Republika Hrvatska započela s izgradnjom pravnog sustava suzbijanja trgovanja ljudima 2002. godine, zakonska regulacija ove materije još uvijek je nedostatna, zbog čega su važna pitanja prepuštena protokolima. Autorice upućuju na neadekvatnu pravnu prirodu protokola kojima se uređuje ova materija te predlažu više mogućih rješenja. Analizirana je i nedavna presuda Europskog suda za ljudska prava u predmetu S. M. protiv Hrvatske, koja jasno ilustrira probleme pri progonu počinitelja. Posljednji dio rada analizira novi Nacionalni plan za suzbijanje trgovanja ljudima te upozorava na očigledne propuste u području mjera i aktivnosti za identifikaciju žrtava, prevenciju trgovanja djecom migrantima te zaštitu žrtava od ponovnog trgovanja ili progona po povratku u zemlju podrijetla.

Ključne riječi: trgovanje ljudima, Nacionalni plan za suzbijanje trgovanja ljudima, protokoli, Europski sud za ljudska prava, žrtve trgovanja ljudima

* Dr. sc. Lana Ofak, izvanredna profesorica Pravnog fakulteta Sveučilišta u Zagrebu, Trg Republike Hrvatske 14, Zagreb; lofak@pravo.hr;

ORCID ID: orcid.org/0000-0001-7585-6370

** Dr. sc. Maja Munivrana Vajda, izvanredna profesorica Pravnog fakulteta Sveučilišta u Zagrebu, Trg Republike Hrvatske 14, Zagreb; mmunivra@pravo.hr; ORCID ID: orcid.org/0000-0001-9496-6102

*** Ovaj rad izrađen je u okviru projekta Multidisciplinary Research Cluster on Crime in Transition - Trafficking in Human Beings, Corruption and Economic Crime, koji financira Hrvatska zaklada za znanost. 


\section{UVOD ${ }^{* * *}$}

Trgovanje ljudima jedan je od najtežih oblika povrede ljudskih prava, dostojanstva i integriteta čovjeka. ${ }^{1}$ Republika Hrvatska započela je s izgradnjom pravnog sustava suzbijanja trgovanja ljudima 2002. godine ratificiravši Konvenciju Ujedinjenih naroda protiv transnacionalnoga organiziranog kriminaliteta iz 2000. godine (stupila na snagu 29. rujna 2003.), Protokol za sprječavanje, suzbijanje i kažnjavanje trgovanja ljudi, posebice žena i djece iz 2000. godine (stupio na snagu 25. prosinca 2003.) te Protokol protiv trgovanja migranata kopnom, morem i zrakom, kojima se dopunjuje Konvencija Ujedinjenih naroda protiv transnacionalnoga organiziranog kriminaliteta (stupio na snagu 28. siječnja 2004.). ${ }^{2}$ Daljnji važan korak ostvaren je ratifikacijom Konvencije Vijeća Europe o suzbijanju trgovanja ljudima iz 2005. godine ${ }^{3}$ (stupila na snagu 1. veljače 2008.), kao i usklađivanjem s Direktivom 2011/36/EU o prevenciji i suzbijanju trgovanja ljudima i zaštiti njegovih žrtava u procesu pristupanja Hrvatske Europskoj uniji.

Cilj ovog rada je dati kritički osvrt na pravni i institucionalni okvir za suzbijanje trgovanja ljudima u Republici Hrvatskoj, ali i predložiti preporuke za njegovo poboljšanje. Rad je podijeljen u tri dijela (drugo, treće i četvrto poglavlje). Prvi dio bavi se nedostatkom zakonske regulacije materije suzbijanja trgovanja ljudima, zbog čega su važna pitanja vezana za sprječavanje trgovanja ljudima i zaštitu prava žrtava prepuštena uređivanju putem nenormativnih akata. Drugi dio sadržava prikaz recentne presude Europskog suda za ljudska prava u predmetu S. M. protiv Hrvatske (zahtjev br. 60561/14). Riječ je o jedinoj presudi

1 Od 2002. do 2016. godine ukupni broj identificiranih žrtava trgovanja ljudima u Hrvatskoj iznosio je 252, od čega su 207 bile žene i djevojčice, tj. 82,14 \% (Vlada Republike Hrvatske, Nacionalni odbor za suzbijanje trgovanja ljudima, Nacionalni plan za suzbijanje trgovanja ljudima za razdoblje od 2018. do 2021. godine, Zagreb, 2018., str. 3).

2 Zakon o potvrđivanju Konvencije Ujedinjenih naroda protiv transnacionalnoga organiziranog kriminaliteta, Protokola za sprječavanje, suzbijanje i kažnjavanje krijumčarenja ljudi, posebice žena i djece te Protokola protiv krijumčarenja migranata kopnom, morem i zrakom, kojima se dopunjuje Konvencija Ujedinjenih naroda protiv transnacionalnoga organiziranog kriminaliteta (Narodne novine, Međunarodni ugovori, br. 14/2002). Budući da je nakon izvršenog uspoređivanja s izvornim tekstom Konvencije i protokola utvrđena pogreška, objavljen je Ispravak Zakona o potvrđivanju Konvencije i protokola (Narodne novine, Međunarodni ugovori, br. 11/2004) u kojima je riječ "krijumčarenje” zamijenjena riječju "trgovanje".

3 Zakon o potvrđivanju Konvencije Vijeća Europe o suzbijanju trgovanja ljudima (Narodne novine, Međunarodni ugovori, br. 7/2007). 
tog suda protiv Hrvatske iz područja trgovanja ljudima, koja je istovremeno i važan doprinos još uvijek relativno nerazvijenoj jurisprudenciji tog suda $u$ vezi s člankom 4. Europske konvencije za zaštitu ljudskih prava. Iako iz same presude ne proizlazi jasan zaključak o manjkavosti zakonske regulacije ove materije u Republici Hrvatskoj, ona jasno upućuje na probleme koji se javljaju u praksi pri identifikaciji žrtava i procesuiranju počinitelja trgovanja ljudima. U trećem dijelu upućuje se na manjkavosti novog Nacionalnog plana za suzbijanje trgovanja ljudima za razdoblje od 2018. do 2021. godine u vidu propusta da predvidi dostatne mjere i aktivnosti u području identifikacije žrtava, prevencije trgovanja djecom zahvaćenom europskom migrantskom krizom te zaštite žrtava od ponovnog trgovanja ili progona po povratku u zemlju podrijetla. Četvrto, zaključno poglavlje sumira glavne zaključke i prijedloge de lege ferenda.

\section{PRAVNI I INSTITUCIONALNI OKVIR ZA SUZBIJANJE TRGOVANJA LJUDIMA U REPUBLICI HRVATSKOJ}

Razvoj institucionalnog okvira za suzbijanje trgovanja ljudima u Hrvatskoj započeo je i prije ratifikacije Konvencije UN-a protiv transnacionalnoga organiziranog kriminaliteta i njezinih protokola 2002. godine formiranjem Nacionalnog odbora za suzbijanje trgovanja ljudima (dalje u tekstu: Nacionalni odbor). Vlada Republike Hrvatske osnovala je Nacionalni odbor svojom Odlukom ${ }^{4}$ na temelju tadašnje odredbe Zakona o Vladi ${ }^{5}$ koja joj dodjeljuje ovlast da osniva stalna i povremena radna tijela za davanje prijedloga, mišljenja, odnosno stručnih obrazloženja o pitanjima iz svojega djelokruga (članak 23.). ${ }^{6} \mathrm{~S}$ obzirom na to da se sukladno članku 23. stavku 3. stalna radna tijela osnivaju poslovnikom, a povremena radna tijela odlukom, time je Vlada iskazala svoju namjeru da Nacionalni odbor bude njezino povremeno tijelo, poput, primjerice, Nacionalnog odbora za borbu protiv nasilja u sportu (osnovano 2013., preimenovano 2015. u Nacionalni odbor za prevenciju i smanjenje nasilja na sportskim natjecanjima), Vijeća za državnu informacijsku infrastrukturu (osnovano 2016.) i Nacionalnog vijeća za održivi razvoj (osnovano 2018.). Za sva ta tijela karakteristično je da nemaju svoju zakonsku osnovu za osnivanje, odnosno da temelj za njihovo osni-

4 Odluka o osnivanju Nacionalnog odbora za suzbijanje trgovanja ljudima (Narodne novine, br. 54/2002).

5 Zakon o Vladi Republike Hrvatske (Narodne novine, br. 101/1998, 15/2000 i $117 / 2001)$.

6 I trenutno važeći Zakon o Vladi Republike Hrvatske (Narodne novine, br. 150/2011, 119/2014 i 93/2016) propisuje identičnu odredbu o osnivanju stalnih i povremenih radnih tijela Vlade (članak 24.). 
vanje ne proizlazi iz nekog zakona, već je njihovo osnivanje isključivo vezano uz odluku Vlade o tome da joj je za obavljanje određenih poslova iz njezina djelokruga potrebna pomoć tijela $\mathrm{u}$ čijem su sastavu predstavnici (u pravilu čelnici) različitih tijela državne uprave i drugih javnopravnih tijela, a ponekad i drugi važni dionici poput predstavnika organizacija civilnog društva i medija. Međutim, budući da Nacionalni odbor za suzbijanje trgovanja ljudima postoji od 2002. godine (s određenim promjenama u njegovoj nadležnosti i sastavu) ${ }^{7}$, jasno je da je to tijelo stalnog karaktera, samo što za njegovo osnivanje ne postoji pravna osnova koja izvire direktno iz nekog zakona koji bi regulirao materiju koja se na njega odnosi.

Jednako tako ne postoji ni zakonska odredba koja propisuje donošenje Nacionalnog plana za suzbijanje trgovanja ljudima, premda je riječ o obvezi koja proizlazi iz članka 9. stavka 1. Protokola za sprječavanje, suzbijanje i kažnjavanje trgovanja ljudi, posebice žena i djece (poznatog kao Protokol iz Palerma), koji propisuje dužnost država stranaka da utvrde sveobuhvatnu politiku, programe i druge mjere: a) za sprječavanje i borbu protiv trgovanja osobama i b) za zaštitu žrtava trgovanja osobama, posebice ženama i djecom, od ponovnog postajanja žrtvom. Naime, ni nakon ratifikacije UN-ove Konvencije protiv transnacionalnoga organiziranog kriminaliteta i njezinih protokola, kao ni nakon ratifikacije Konvencije Vijeća Europe o suzbijanju trgovanja ljudima, Hrvatska se nije opredijelila za donošenje jedinstvenog zakona kojim bi na jednom mjestu regulirala sva važna pitanja vezana uz sprječavanje i suzbijanje trgovanja ljudima te zaštitu prava žrtava. Posljedica toga je nesistematični pristup uređenju tog područja, što znači da se odredbe o suzbijanju trgovanja ljudima i zaštiti žrtava nalaze u brojnim zakonima koji uređuju različitu materiju (Kazneni zakon, Zakon o kaznenom postupku, Zakon o strancima, Zakon o obveznom zdravstvenom osiguranju i zdravstvenoj zaštiti stranaca u Republici Hrvatskoj, Zakon o međunarodnoj i privremenoj zaštiti, Zakon o socijalnoj skrbi, Zakon o prebivalištu, Zakon o Hrvatskom Crvenom križu itd.). Štoviše, važna pitanja uopće nisu uređena općenormativnim aktima, već je njihova regulacija prepuštena donošenju akata (protokola) koji po svojem pravnom karakteru nisu propisi, što je vrlo atipična metoda uređenja neprimjerena za jednu tako važnu materiju u području zaštite ljudskih prava i temeljnih sloboda koja je od međunarodne, a ne samo nacionalne važnosti (vidi infra poglavlje 2.1.).

7 Odluka o osnivanju Nacionalnog odbora za suzbijanje trgovanja ljudima iz 2002. mijenjana je i dopunjavana tri puta (Narodne novine, br. 41/2004, 122/2009 i 119/2010). Vlada je 2012. godine donijela novu Odluku o osnivanju Nacionalnog odbora za suzbijanje trgovanja ljudima (Narodne novine, br. 42/2012), koja je dosad mijenjana i dopunjavana dvaput (Narodne novine, br. 49/2015 i 30/2018). 
Još je 2002. godine važan zadatak izrade Nacionalnog plana djelovanja na suzbijanju trgovanja ljudima dan u nadležnost Nacionalnog odbora. Nakon njegove izrade Nacionalni plan, na prijedlog Nacionalnog odbora, donosi Vlada Republike Hrvatske. ${ }^{8}$ Od 2002. do danas doneseno je pet nacionalnih planova za suzbijanje trgovanja ljudima, točnije četiri plana i jedan program: (1) Nacionalni plan za suzbijanje trgovanja ljudima 2002., (2) Nacionalni program za suzbijanje trgovanja ljudima od 2005. do 2008. (iznimno je donesen program umjesto plana) $)^{9}$, (3) Nacionalni plan za suzbijanje trgovanja ljudima za razdoblje od 2009. do 2011. godine, (4) Nacionalni plan za suzbijanje trgovanja ljudima za razdoblje od 2012. do 2015. godine i (5) Nacionalni plan za suzbijanje trgovanja ljudima za razdoblje od 2018. do 2021. godine. Osim navedenih planova, u rujnu 2005. godine donesen je i Nacionalni plan za suzbijanje trgovanja djecom (listopad 2005. - prosinac 2007.).

Nijedan od navedenih planova nije objavljen u Narodnim novinama, već im je pristup moguć samo pretraživanjem internetskih stranica Vlade RH ili Središnjeg kataloga službenih dokumenata RH. Zadnja dva plana (2012. - 2015. i 2018. - 2021.) objavljena su na internetskoj stranici Ureda za ljudska prava i prava nacionalnih manjina, koji na godišnjoj razini izvještava Vladu o provedbi nacionalnog plana. Budući da Vlada ima mogućnost odrediti da se akti koje ona donosi objave u Narodnim novinama (vidi članak 32. stavak 2. Zakona o Vladi), nejasan je razlog zašto to godinama propušta učiniti s obzirom na važnost materije o kojoj je riječ. Usporedbe radi, postoje razni primjeri objavljivanja Vladinih planova i programa u Narodnim novinama, kao što su Nacionalni program za razvoj i uvođenje inteligentnih transportnih sustava u cestovnom prometu za razdoblje od 2014. do 2018. godine (Narodne novine, br. 82/2014), Nacionalni program za olakšice (u zračnom prometu, op. a.) (Narodne novine, br. 105/2015) te Nacionalni plan za provedbu Stockholmske konvencije o po-

8 Vidi točku III. Odluke o osnivanju Nacionalnog odbora za suzbijanje trgovanja ljudima (Narodne novine, br. 54/2002, 41/2004, 122/2009 i 119/2010). Novom Odlukom o osnivanju Nacionalnog odbora za suzbijanje trgovanja ljudima (Narodne novine, br. 42/2012, 49/2015 i 30/2018) više nije propisano da Nacionalni odbor izrađuje Nacionalni plan, već da Nacionalni odbor daje smjernice za izradu nacionalnih strategija i planova na području suzbijanja trgovanja ljudima (točka II.). Međutim, novi Nacionalni plan za suzbijanje trgovanja ljudima za razdoblje od 2018. do 2021. godine, koji je Vlada usvojila 7. lipnja 2018., u svojem zaglavlju i dalje sadržava naziv tijela: Vlada Republike Hrvatske, Nacionalni odbor za suzbijanje trgovanja ljudima.

9 U razdoblju od 2005. do 2008. svake se godine donosio godišnji operativni plan za razradu programskih ciljeva predviđenih Nacionalnim programom za suzbijanje trgovanja ljudima od 2005. do 2008. 
stojanim organskim onečišćujućim tvarima u Republici Hrvatskoj (Narodne novine, br. 62/2016).

\subsection{Pravna priroda protokola kojima se uređuju prava žrtava i postupanja nadležnih tijela u slučajevima trgovanja ljudima}

$\mathrm{Na}$ temelju nacionalnih planova za suzbijanje trgovanja ljudima doneseni su protokoli kojima se uređuju određena postupanja u konkretnim slučajevima trgovanja ljudima, kao i prava žrtava. Prvi protokol postupanja u vezi s detekcijom i zbrinjavanjem žrtava trgovanja ljudima donio je Nacionalni odbor 2003. godine. Zatim je Vlada u studenome 2008. godine zaključkom usvojila Protokol za identifikaciju, pomoć i zaštitu žrtava trgovanja ljudima, koji je u rujnu 2017. zamijenila novim. Osim toga, Vlada je u prosincu 2009. prihvatila Protokol o postupanju pri dobrovoljnom povratku žrtava trgovanja ljudima. I taj je Protokol u rujnu 2017. zamijenila novim. Treći važan protokol koji uređuje prava žrtava jest Protokol o integraciji/reintegraciji žrtava trgovanja ljudima, koji je Vlada usvojila u svibnju 2011., a dosad još nije bio mijenjan.

Nijedan od navedenih protokola nije objavljen u Narodnim novinama ${ }^{10}$, niti postoji zakonska osnova za njihovo donošenje, što se odražava u nedostatku preambule, koja se inače nalazi na početku svakog propisa, a sadržava naznaku pravne osnove za njegovo donošenje. $\mathrm{S}$ druge strane, u završnim odredbama svih protokola propisana je dužnost postupanja u skladu s njima, kao i dan njihova stupanja na snagu, a to je dan usvajanja od strane Vlade Republike Hrvatske, izuzev Protokola o integraciji/reintegraciji u kojem je propisano da stupa na snagu 1. siječnja 2012. godine.

Sva tri protokola pisana su normativnim stilom u formi članaka kojima se određuju obveze nadležnim tijelima, ali i uređuju prava žrtava trgovanja ljudima. Primjerice, Protokol za identifikaciju, pomoć i zaštitu žrtava trgovanja ljudima u pojedinim svojim odredbama uređuje način vođenja upravnog postupka, tj. način odlučivanja o dodjeljivanju statusa žrtve, kao i gubitku tog statusa. Navedeni Protokol sadržava odredbe kojima se, bez ikakve zakonske osnove, dopunjuju odredbe Zakona o strancima ${ }^{11}$, a postupak donošenja odluke o dodjeljivanju

10 Protokoli su na dan njihova usvajanja objavljeni na internetskoj stranici Vlade RH pod rubrikom dokumenti u okviru sjednice na kojoj su doneseni (https://vlada.gov. hr/ (17. kolovoza 2018.)), a neutvrđenog datuma objavljeni su i na internetskoj stranici Ureda za ljudska prava i prava nacionalnih manjina pod rubrikom ljudska prava, suzbijanje trgovanja ljudima (https://ljudskaprava.gov.hr/ (17. kolovoza 2018.)).

11 Primjerice, u članku 3. Protokola propisuje se da žrtvi status može dodijeliti Ministarstvo unutarnjih poslova ili Operativni tim Nacionalnog odbora za suzbijanje 
i gubitku statusa žrtve uređuje se na način koji je protivan Zakonu o općem upravnom postupku (dalje u tekstu: ZUP). ${ }^{12}$ Nikakvim podzakonskim propisom nije moguće ni dopušteno odstupanje od odredaba ZUP-a, a kamoli aktom za koji je upitno je li uopće po svojem pravnom karakteru propis. ${ }^{13}$

Ustavni sud Republike Hrvatske u svojoj praksi imao je priliku baviti se pitanjem pravne prirode akata državnih tijela koji nisu objavljeni u Narodnim

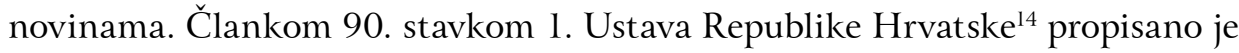
da se prije nego što stupe na snagu drugi propisi državnih tijela objavljuju u Narodnim novinama, službenom listu Republike Hrvatske. Stajalište je Ustavnog suda da sukladno citiranoj ustavnoj odredbi:

“...eksterni općenormativni i pravnoobvezujući akti državnih tijela ne mogu stupiti na pravnu snagu ako prethodno nisu objavljeni u 'Narodnim novinama'. Aktom objave u službenom listu oni postaju javno dostupni, a zatim, pod propisanim uvjetima stupaju na snagu, čime postaju primjenjivi, to jest stječu svojstvo općeobveznosti i djeluju prema svim svojim adresatima. Eksterni općenormativni akt državnog tijela koji nije objavljen u 'Narodnim novinama', stoga, nije ni stupio na pravnu snagu, kao takav nije primjenjiv, nije općeobvezan i ne djeluje ni prema kome. Slijedom navedenog, takav akt ne može se smatrati propisom (odnosno 'drugim propisom') te ne može biti ni predmet ustavnosudske ocjene u smislu citiranog članka 125. alineje 2. Ustava." 15

trgovanja ljudima, a takva odredba uopće ne postoji u Zakonu o strancima (Narodne novine, br. 130/2011, 74/2013, 69/2017 i 46/2018), koji u članku 66. stavku 1. propisuje da identifikaciju žrtve obavlja Ministarstvo unutarnjih poslova u suradnji s organizacijama civilnog društva, a kada je riječ o žrtvi maloljetniku, Ministarstvo je dužno surađivati i s ministarstvom nadležnim za socijalnu skrb.

Zakon o općem upravnom postupku (Narodne novine, br. 47/2009).

Članak 3. i članak 14. stavak 5. Protokola propisuju da odluku o dodjeljivanju statusa i gubitku statusa žrtve Operativni tim donosi natpolovičnom većinom svih prisutnih članova. Odredbe su protivne članku 25. stavku 1. ZUP-a sukladno kojemu kolegijalno javnopravno tijelo o upravnim stvarima odlučuje većinom glasova svih članova (ne samo prisutnih), ako nije drukčije propisano. Prema članku 3. stavku 1. ZUP-a samo se pojedina pitanja upravnog postupka mogu zakonom urediti drukčije, ako je to nužno za postupanje u pojedinim upravnim područjima te ako to nije protivno temeljnim odredbama i svrsi ZUP-a.

14 Ustav Republike Hrvatske, Narodne novine, br. 56/1990, 135/1997, 113/2000, 28/2001, 76/2010 i 5/2014.

15 Rješenje Ustavnog suda, U-II-3209/2013 i U-II-4311/2013 od 19. prosinca 2013., točka 6.2 . 
Međutim, činjenica je da u hrvatskoj upravnoj praksi ipak postoje akti koji formalnopravno nisu stupili na snagu jer nisu objavljeni u Narodnim novinama, ali se - neovisno o tomu - primjenjuju i proizvode pravne i de facto učinke kao da su objavljeni u Narodnim novinama i kao da su stupili na snagu. Za takve situacije Ustavni sud zauzeo je sljedeće stajalište:

"Ustavnom sudu ne preostaje drugo nego utvrditi nesuglasnost opisane administrativne (upravne) prakse neobjavljivanja propisa u 'Narodnim novinama' s člancima 3. (u dijelu koji se tiče vladavine prava) i 5. u vezi s člankom 90. stavkom 1. Ustava i okrenuti se budućnosti, to jest svojom odlukom spriječiti ponavljanje takve neustavne administrativne prakse..."16

Mjera koju Ustavni sud u tim situacijama poduzima jest davanje naloga državnom tijelu da akt o kojem je riječ objavi u Narodnim novinama i u njemu izrijekom odredi njegovo stupanje na snagu poslije te objave u roku koji je $u$ skladu s ustavnim zahtjevima. ${ }^{17}$

Međutim, protokoli kojima se uređuju prava žrtava i postupanja nadležnih tijela u slučajevima trgovanja ljudima razlikuju se od akata o kojima je Ustavni sud odlučivao u prethodno citiranom predmetu U-II-2168/2013 i dr. po tome što ne postoji zakonska odredba kojom se Vlada ovlašćuje za donošenje tih protokola. Sukladno načelu zakonitosti, nijedan podzakonski općenormativni akt ne može biti donesen bez odgovarajućeg prethodnog ovlaštenja propisanog u zakonu kojim se njegovu donositelju daje nadležnost za njegovo donošenje. To se u upravnopravnoj teoriji naziva egzistencijsko djelovanje načela zakonitosti prema podzakonskim općenormativnim aktima. ${ }^{18}$ Stoga se protokoli o kojima je riječ nikako ne mogu smatrati propisima jer su doneseni bez ikakvog uporišta u višoj pravnoj normi i ne služe za provedbu nikakvog zakona s obzirom na to da jedinstven zakon koji bi uređivao područje postupanja u slučajevima trgovanja ljudima u Hrvatskoj ne postoji. Međunarodni ugovori koji sadržavaju norme kojima se propisuju određene obveze za države ugovornice, a koje nemaju samoizvršivi (self-executing) karakter, zbog ustavnog načela diobe vlasti zahtijevaju da zakonodavac bude taj koji će provesti regulatornu djelatnost potrebnu za usklađivanje s međunarodnim normama.

Kakva je onda pravna priroda tih protokola, premda su pisani kao da je riječ o propisu te se u njima određuje njihova obveznost i stupanje na snagu? Sukladno Zakonu o Vladi, Vlada donosi zaključke kojima se utvrđuju stajališta

16 Odluka Ustavnog suda, U-II-2168/2013 i dr. od 15. travnja 2014., točka 8.2.

17 Ibid., vidi točku III. izreke Odluke.

18 Ivančević, V., Institucije upravnog prava, Pravni fakultet u Zagrebu, Zagreb, 1983., str. 90 i 194; Borković, I., Upravno pravo, Informator, Zagreb, 1997., str. 63. 
Vlade u pitanjima provedbe utvrđene politike te određuju zadaće tijelima državne uprave (članak 31. stavak 3.). Sve protokole Vlada je usvojila donošenjem zaključka o njihovu prihvaćanju. Zaključci po svojoj pravnoj prirodi nisu propisi, za razliku od uredaba, i nemaju eksterni učinak (prema trećima). Problem koji se javlja kod protokola jest $\mathrm{u}$ tome što su oni doneseni sa svrhom da se njima uredi način postupanja nadležnih tijela: (1) tijekom identifikacije, pružanja pomoći i zaštite žrtava trgovanja ljudima, (2) u slučaju njihova dobrovoljnog povratka u zemlju podrijetla odnosno zemlju u koju se žrtva premješta te (3) prilikom integracije odnosno reintegracije žrtava u društvo. Protokoli u tom pogledu sadržavaju i odredbe kojima se propisuju prava koja žrtve trgovanja ljudima imaju te nadležnost tijela koja o njihovim pravima odlučuju. Budući da protokoli formalnopravno nisu propisi, oni zapravo potpadaju pod kategoriju internih naputaka (instrukcija, uputa) kao posebne vrste akata putem kojih više tijelo nižem tijelu ili tijelima podjeljuje upute za postupanje ili djelovanje u određenim situacijama. ${ }^{19}$

Interni naputak nije podzakonski propis i na njega se ne mogu pozivati treće osobe. ${ }^{20}$ Posljedica toga je da nadležno tijelo svoje akte i mjere ne može temeljiti na podijeljenom naputku, nego samo na zakonu i drugom propisu. Sukladno načelu zakonitosti propisanom u Ustavu (članak 19. stavak 1.), pojedinačni akti državne uprave i tijela koja imaju javne ovlasti moraju biti utemeljeni na zakonu. Nadalje, i ZUP propisuje načelo zakonitosti sukladno kojemu javnopravno tijelo rješava upravnu stvar na temelju zakona i drugih propisa te općih akata donesenih na temelju zakonom utvrđenih javnih ovlasti (članak 5. stavak 1.). To znači da se upravne stvari ne smiju rješavati na temelju internih naputaka. Žrtve trgovanja ljudima ne mogu, pozivajući se na odredbe protokola, tražiti ostvarenje većih prava nego što im to priznaje neka odredba zakona ili podzakonskog propisa ${ }^{21}$ Osim toga, naputak ima savjetodavnotehnički karakter te ne obvezuje tijelo kojemu je dodijeljeno, osim ako je njegova obveznost propisana zakonom. ${ }^{22} \mathrm{U}$ slučaju protokola, iako oni u svojim odredbama sadržavaju dužnost postupanja po njima, s obzirom na to da takva obveznost protokola nije predviđena nekim zakonom, ona nema nikakav pravni učinak. Sankcije koje proizlaze iz eventualnog nepoštovanja naputaka, pa tako i tih protokola, kreću

19 Borković, op. cit. u bilj. 18, str. 98.

20 U tom smislu interne naputke treba strogo razlikovati od naputaka (vrste provedbenih propisa) koje su, sukladno članku 18. Zakona o sustavu državne uprave (Narodne novine, br. 150/2011, 12/2013, 93/2016 i 104/2016), ovlašteni donositi čelnici središnjih tijela državne uprave ako ih na to izrijekom ovlasti neki zakon.

21 Usp. Borković, op. cit. u bilj. 18, str. 99.

22 Ibid., str. 99 - 100; Ivančević, op. cit. u bilj. 18, str. 73. 
se u okvirima disciplinske odgovornosti, odnosno odgovornosti za povrede službene dužnosti. ${ }^{23}$

Premda ne sadrži izričite odredbe o trgovanju ljudima, Konvencija za zaštitu ljudskih prava i temeljnih sloboda ${ }^{24}$ (dalje u tekstu: Europska konvencija) primjenjuje se i na takve slučajeve (vidi infra poglavlje 3.), a dužnost države da zaštiti žrtve trgovanja ljudima proizlazi iz njezina članka 4. koji zabranjuje ropstvo i prisilan rad. Stoga zaista čudi opredjeljenje hrvatske Vlade da za tako važnu materiju koja je regulirana međunarodnim ugovorima ne predloži donošenje jednog cjelovitog zakona, već se u velikoj mjeri služi pravno neobvezujućim aktima (planovima i protokolima) koji nisu ni objavljeni u Narodnim novinama. U tom pogledu preporuka za poboljšanje pravnog okvira i mjera za suzbijanje i prevenciju sprječavanja trgovanja ljudima je donošenje Zakona o suzbijanju trgovanja ljudima u kojem bi se uredila sva pitanja vezana uz prava koja žrtve trgovanja ljudima imaju te nadležnost i postupanje tijela koja o njihovim pravima odlučuju.

Alternativno, ako se smatra da trgovanje ljudima u Hrvatskoj još uvijek nije toliko znatan problem koji zaslužuje regulaciju posebnim zakonom, tada je nužno u druge zakone koji sadržavaju pojedine norme o pravima žrtava trgovanja ljudima (primjerice, Zakon o strancima, Zakon o socijalnoj skrbi i Zakon o kaznenom postupku) unijeti izričitu ovlast Vlade za donošenje podzakonskih propisa koji bi zamijenili dosadašnje pravno neobvezujuće protokole. Nadalje, važno je istaknuti da smatramo neprimjerenim postupak dodjeljivanja statusa žrtve i određivanje njihovih prava regulirati Zakonom o strancima s obzirom na to da žrtve trgovanja ljudima nisu isključivo strani državljani, već praksa pokazuje povećanje broja žrtava trgovanja ljudima koje su državljani Republike Hrvatske. ${ }^{25}$ Stoga ne postoji razumno objašnjenje zašto bi se njihova prava uređivala zakonom koji se odnosi samo na strane državljane.

Još jedna mogućnost za poboljšanje pravnog okvira jest da se protokoli zadrže, ali da se njihov sadržaj izmjeni odnosno uskladi s činjenicom da nije riječ o propisima. U tom smislu protokoli ne bi smjeli biti pisani normativnim stilom u obliku članaka, već bi trebali biti sastavljeni kao naputci za postupanje nadležnih tijela u kojima se ne propisuju nikakve odredbe, nego se na sistematičan način pojašnjava nadležnim tijelima način izvršavanja njihovih obveza

23 Usp. Borković, op. cit. u bilj. 18, str. 99.

24 Konvencija za zaštitu ljudskih prava i temeljnih sloboda, Narodne novine, Međunarodni ugovori, br. 18/1997, 6/1999 - pročišćeni tekst, 8/1999 - ispravak, 14/2002 i $1 / 2006$.

25 Nacionalni plan... od 2018. do 2021. godine, op. cit. u bilj. 1, str. 6. 
propisanih zakonom i drugim propisima. ${ }^{26}$ Osim toga, bilo bi nužno provesti detaljnu analizu odredaba protokola te identificirati one odredbe koje ne postoje u zakonu i kojima se zapravo nadopunjuje zakon, jer je takva pojava protivna načelu zakonitosti. Odredbe iz protokola koje nedostaju u zakonu trebale bi se uvrstiti u sam zakon.

\section{PRAKSA EUROPSKOG SUDA ZA LJUDSKA PRAVA U SLUČAJEVIMA TRGOVANJA LJUDIMA U ODNOSU NA REPUBLIKU HRVATSKU}

Europski sud za ljudska prava (dalje u tekstu: ESLJP) do sada je odlučivao o samo jednom slučaju iz područja članka 4. Europske konvencije u odnosu na Republiku Hrvatsku. Riječ je o predmetu S. M. protiv Hrvatske. ${ }^{27}$ Presuda u tom predmetu, donesena 19. srpnja 2018. godine, važna je ne samo zato što se odnosi na Republiku Hrvatsku već i stoga što predstavlja doprinos još uvijek relativno siromašnoj sudskoj praksi ESLJP-a na području članka 4. Europske konvencije i trgovanja ljudima. ${ }^{28}$ Još u čuvenoj presudi Rantsev protiv Cipra i Rusije iz 2010. godine ESLJP je zaključio kako je trgovanje ljudima obuhvaćeno člankom 4. Europske konvencije, iako ga taj članak izrijekom ne navodi ${ }^{29}$, no u tom je predmetu, čini se, ESLJP otišao i korak dalje. Naime, Sud je eksplicitno naveo

26 Primjer jednog kvalitetno sastavljenog protokola jest Protokol o postupanju u slučaju seksualnog nasilja (Narodne novine, br. 70/2018).

27 ESLJP, S. M. protiv Hrvatske, zahtjev br. 60561/14, presuda od 19. srpnja 2018. godine dostupna je na engleskom jeziku putem baze podataka HUDOC, koja omogućuje pristup praksi ESLJP-a, https://hudoc.echr.coe.int/eng (22. kolovoza 2018.). U vrijeme pisanja ovog rada još nije načinjen njezin prijevod na hrvatski jezik.

28 O praksi Europskog suda za ljudska prava u odnosu na članak 4. Europske konvencije općenito vidi Herceg Pakšić, B.; Jukić, M., Primjena konvencijskog prava u području zabrane ropstva i prisilnog rada: europski standardi i hrvatska postignuća, Hrvatski ljetopis za kaznene znanosti i praksu, vol. 23, br. 2, 2016., str. $281-310$.

29 U predmetu Rantsev protiv Cipra i Rusije, zahtjev br. 25965/04, presuda od 7. siječnja 2010. godine, par. 282., ESLJP istaknuo je da trgovanje ljudima predstavlja oblik modernog ropstva i napad na ljudsko dostojanstvo nekompatibilan s demokratskim vrijednostima Europske konvencije, te je stoga samostalno obuhvaćeno zabranom iz članka 4. Konvencije, bez potrebe da se podvede pod pojam "ropstva", "servituta" ili "prisilnog rada". Sud je pritom smatrao kako se elementi trgovanja ljudima kao što su tretiranje ljudi kao robe, bliski nadzor, ograničenje kretanja, uporaba sile ili prijetnji, loši uvjeti života i rada te mala ili nikakva plaća podudaraju sa svim trima kategorijama eksplicitno zabranjenim člankom 4. Konvencije. V. i par. 56. presude u predmetu S. M. protiv Hrvatske, op. cit. u bilj. 27. 
da je ne samo trgovanje ljudima već i iskorištavanje za prostituciju obuhvaćeno člankom 4. Europske konvencije, i to čak i onda kada nema internacionalnog elementa. Naime, prema ESLJP-u nema sumnje da "trgovanje ljudima i iskorištavanje za prostituciju prijete ljudskom dostojanstvu i temeljnim slobodama njihovih žrtava, pa ne mogu biti kompatibilni s demokratskim društvom i temeljnim vrijednostima koje promiče Konvencija." ${ }^{30}$ Imajući u vidu obvezu da Konvenciju primjenjuje u svijetlu današnjih uvjeta, ESLJP je smatrao nepotrebnim utvrditi predstavlja li tretman kojem je bila podvrgnuta podnositeljica zahtjeva 'ropstvo', 'ropstvu sličan odnos', ili 'prisilni rad'. Umjesto toga, Sud je zaključio da "trgovanje ljudima kao i iskorištavanje za prostituciju, u okviru značenja članka 3(a) Protokola iz Palerma, članka 4(a) Konvencije Vijeća Europe o suzbijanju trgovanja ljudima, članka 1. Konvencije o suzbijanju trgovanja ljudima i iskorištavanja drugih za prostituciju i Konvencije o uklanjanju svih oblika diskriminacije prema ženama, potpada pod doseg članka 4. Europske Konvencije". ${ }^{31}$ Stoga je i zahtjev podnositeljice odlučio razmotriti kao potencijalnu povredu članka 4. Europske konvencije. U konkretnom predmetu podnositeljica zahtjeva podnijela je kaznenu prijavu protiv T. M. navodeći da ju je on tijekom ljeta i u rujnu 2011. godine fizički i psihički prisiljavao na prostituciju. Državno odvjetništvo optužilo je T. M.-a da je podnositeljicu prisilio na prostituciju, čime je prema tada važećem Kaznenom zakonu počinio kvalificirano kazneno djelo podvođenja ${ }^{32}$, no T. M. je u konačnici oslobođen optužbi zbog nedostatka dokaza. ${ }^{33}$ ESLJP je ponovio kako članak 4. Europske konvencije sadržava pozitivnu obvezu država stranaka da inkriminiraju i učinkovito procesuiraju svaku radnju usmjerenu prema zadržavanju osobe u stanju ropstva, servituta i prisilnog rada, kao i to da predvide mjere zaštite žrtava i pruže im podršku. ${ }^{34}$ ESLJP je nadalje naglasio da, kao i neki drugi članci, članak 4. sadržava u sebi procesnu obvezu

30 Ibid., par. 54.

31 Ibid. Sud je istovremeno podsjetio na to kako, da bi bila riječ o trgovanju ljudima, internacionalni element nije nužan te je moguće da podnositeljica zahtjeva ima državljanstvo države koju tuži.

32 Vidi članak 195. Kaznenog zakona iz 1997. godine, Narodne novine, br. 110/1997, 27/1998, 50/2000, 129/2000, 51/2001, 111/2003, 190/2003, 105/2004, 84/2005, 71/2006, 110/2007, 152/2008, 57/2011 i 143/2012. Danas bi bila riječ o kaznenom djelu prostitucije iz članka 157. stavka 2. novog Kaznenog zakona, Narodne novine, br. 125/2011, 144/2012, 56/2015, 61/2015 i 101/2017.

33 Sažetak sa stranice Ureda zastupnika Republike Hrvatske pred Europskim sudom za ljudska prava, https://uredzastupnika.gov.hr/vijesti/nova-presuda-s-m-protiv-hrvatske/374 (24. kolovoza 2018.).

34 S. M. protiv Hrvatske, op. cit. u bilj. 27, par. 57. i 58. s pozivom na predmet Siliadin protiv Francuske, zahtjev br. 73316/01, presuda od 26. srpnja 2005., par. 112. - 120. 
istrage kada postoji vjerodostojna sumnja da su prava pojedinca povrijeđena. Naravno, svi postupci ne moraju rezultirati osudama okrivljenika, no ono što ESLJP ispituje jest u kojoj su mjeri nacionalna tijela i sudovi podvrgnuli slučaj pažljivom ispitivanju (engl. careful scrutiny). ${ }^{35}$ Upravo u tom segmentu ESLJP je našao povredu od strane Republike Hrvatske. Naime, dok je ESLJP smatrao prva dva aspekta zadovoljenim (postojao je odgovarajući zakonodavni okvir i podnositeljici je pružena zaštita), u pogledu trećeg je primijetio kako nije poduzet niz koraka ni ozbiljan napor da se istraže okolnosti koje bi bile relevantne za ocjenu je li T. M. prisilio podnositeljicu na prostituciju (među ostalim, nisu ispitani potencijalno relevantni svjedoci, nije se pokušala utvrditi prava priroda odnosa između podnositeljice zahtjeva i T. M. niti su nacionalna tijela pokušala doći do klijenata). ${ }^{36}$ Nadalje, ESLJP je upozorio na olako odbacivanje žrtvina svjedočenja od strane nacionalnog suda. Naime, hrvatski sud ocijenio je žrtvino svjedočenje kao nevjerodostojno jer je zvučalo nekoherentno te je žrtva izgledala nesigurno i oklijevala je tijekom davanja iskaza. Pritom hrvatski sudovi nisu uzeli u obzir potencijalni učinak psihološke traume na žrtvu i njezinu mogućnost da se konzistentno i jasno izrazi o okolnostima svojeg iskorištavanja. ${ }^{37}$ Iz tih razloga ESLJP je pronašao povredu procesnog aspekta članka 4. Europske konvencije. ${ }^{38}$

Osim što upućuje na propuste u radu hrvatskog pravosuđa i probleme koji se u praksi javljaju pri progonu počinitelja trgovanja ljudima, ta presuda postavlja općenito pitanje razgraničenja između trgovanja ljudima i iskorištavanja za prostituciju. I u našem kaznenopravnom sustavu obilježja kaznenog djela trgovanja ljudima iz članka 106. st. 1. te prostitucije iz članka 157. st. 2. Kaznenog zakona podudaraju se, zbog čega u praksi vrlo lako može doći do pojave da se trgovanje ljudima kvalificira kao prostitucija, na što upozoravaju i neka međunarodna izvješća. ${ }^{39} \mathrm{U}$ hrvatskom pravnom sustavu prostitucija, uključujući i bavljenje prostitucijom, nezakonita je, no odnos prema prostituciji znatno je različit u državama članicama Vijeća Europe. Imajući to u vidu, u svojem suprotstavljenom mišljenju sutkinja Koskelo upozorila je na to da je pojam 'iskorištavanje za prostituciju' nedovoljno određen, pa je njegovo podvođenje pod članak 4. Europske

35 Ibid., par. 59.

36 Ibid., par. 68. - 72., 77. - 79.

37 Ibid., par. 80. Imajući u vidu i ranjivost žrtava spolnog nasilja, ESLJP je smatrao mogućim i da je negativan učinak na žrtvu imao i kratak susret s okrivljenikom u sudnici unatoč tomu što je okrivljenik ubrzo udaljen.

38 Ipak, treba upozoriti na to da presuda u trenutku dovršetka ovog rada nije još bila konačna te postoji mogućnost da će o slučaju odlučivati Veliko vijeće.

39 Vidi Concluding Observations on Croatia of 28 July 2015 (CEDAW/C/HRV/CO/45), par. 20. Predviđena kazna za oba djela je ista, od jedne do deset godina zatvora. 
konvencije, a pogotovo inkriminiranje, sporno s aspekta načela zakonitosti, a ujedno je i znatno proširenje dosega čl. 4. Europske konvencije. ${ }^{40}$ Naime, ovisno o kutu gledanja, može se smatrati kako svaka prostitucija sadržava u sebi element iskorištavanja. Naravno, trgovanje ljudima, osim kad je riječ o djeci, nužno sadržava element prisile, a prostitucija ne - no imajući u vidu da pristanak osobe na iskorištavanje ne isključuje postojanje ni kaznenog djela trgovanja ljudima ni kaznenog djela iskorištavanja za prostituciju te da prisila može postojati ne samo kao primjena sile ili prijetnje nego i u obliku iskorištavanja ranjivosti žrtve - jasno je da je granica između tih dvaju djela tanka. Stoga bi, uvijek kada je riječ o iskorištavanju druge osobe za prostituciju, posebnu pažnju trebalo posvetiti ispitivanju jesu li ostvarena i obilježja trgovanja ljudima.

\section{PREPORUKE ZA POBOLJŠANJE MJERA ZA SUZBIJANJE I PREVENCIJU TRGOVANJA LJUDIMA U POJEDINIM PODRUČJIMA}

Trgovanje ljudima spada među jednu od najprofitabilnijih vrsta kaznenih djela u svijetu ${ }^{41}$, a ujedno i među najokrutnije primjere kršenja ljudskih prava. Stoga ne čudi da međunarodna zajednica pokazuje velik interes za istraživanje načina kako poboljšati nacionalne sustave za suzbijanje i prevenciju trgovanja ljudima i unaprijediti zaštitu žrtava. U ovom završnom dijelu rada, na temelju analize dostupnih recentnih znanstvenih istraživanja vezanih uz trgovanje ljudima, dat će se kritički osvrt na pojedine mjere predviđene novim Nacionalnim planom za suzbijanje trgovanja ljudima za razdoblje od 2018. do 2021. godine (dalje u tekstu: Nacionalni plan 2018. - 2021.) te ponuditi dodatne preporuke u svrhu poboljšanja domaćeg sustava za suzbijanje i prevenciju trgovanja ljudima.

40 S. M. protiv Hrvatske, op. cit. u bilj. 27, par. 19. suprotstavljenog mišljenja sutkinje Koskelo.

${ }^{41}$ Sl. i Derenčinović, D., Nisu na prodaju - o pravima žrtava trgovanja ljudima nakon presude Europskog suda za ljudska prava u predmetu Rantsev protiv Cipra i Rusije, Godišnjak Akademije pravnih znanosti Hrvatske, vol. 1, br. 1, 2010., str. 54. Vidi i European Commission, The EU Strategy towards the Eradication of Trafficking in Human Beings 2012-2016, COM(2012) 286 final, Brussels, 19. lipnja 2012. 


\subsection{Postupak identifikacije žrtava i potreba proširenja ciljanih skupina kojima se pruža edukacija}

Pravodobna identifikacija žrtava trgovanja ljudima glavni je uvjet koji mora biti ispunjen za primjenu zakona koji se odnose na kazneni progon i kažnjavanje počinitelja tog kaznenog djela. Kako bi se uopće neka osoba mogla otkriti i identificirati kao žrtva trgovanja ljudima, mora postojati kontakt te osobe i policijskih službenika, a do tog kontakta u konkretnim situacijama ne mora doći. Stoga je nužno poticati i uspostaviti suradnju između policijskih službenika i osoba koje imaju veću učestalost kontakata sa žrtvama trgovanja ljudima kako žrtve ne bi ostale neotkrivene. Među osobe s većom učestalošću kontakata s žrtvama osobito spadaju zdravstveni djelatnici. ${ }^{42}$

Pregledom Nacionalnog plana 2018. - 2021., kao i prethodnih planova te godišnjih izvješća o provedbi prethodnih nacionalnih planova, utvrđeno je da se zdravstveni djelatnici uključuju u postupak zaštite žrtava tek nakon što su one već identificirane. Na taj način problemu se pristupa na reaktivan način. Umjesto da se proaktivno stvore uvjeti kojima bi se povećala vjerojatnost za otkrivanje i identifikaciju žrtava, Nacionalni plan predviđa suradnju sa zdravstvenim ustanovama i uključivanje zdravstvenih djelatnika u njegovu provedbu tek kod osiguranja oporavka i reintegracije žrtava u društvo ${ }^{43}$ odnosno kod pružanja pomoći i zaštite već identificiranim žrtvama. ${ }^{44}$

42 Vidi Helton, M., Human Trafficking: How a Joint Task Force Between Health Care Providers and Law Enforcement Can Assist with Identifying Victims and Prosecuting Traffickers, Health Matrix, vol. 26, br. 1, 2016., str. 433 - 473.

43 Vidi Cilj 2. Osigurati oporavak i integraciju/reintegraciju žrtava trgovanja ljudima u društvo, Mjera 1. Unaprijediti suradnju sa zdravstvenim, socijalnim i obrazovnim ustanovama, Aktivnost 1. Koordinacija aktivnosti u individualnim slučajevima trgovanja ljudima između zdravstvenih, socijalnih i obrazovnih ustanova s predstavnicima tijela državne uprave nadležnim za poslove zdravstvene zaštite i socijalne skrbi, a koji su članovi Operativnog tima Nacionalnog odbora za suzbijanje trgovanja ljudima - Vlada Republike Hrvatske, Nacionalni odbor za suzbijanje trgovanja ljudima, Nacionalni plan za suzbijanje trgovanja ljudima za razdoblje od 2012. - 2015., Zagreb, 2012., str. 12.

44 Vidi Cilj 1. Osigurati zaštitu najboljeg interesa žrtava trgovanja ljudima, Mjera 1. Osigurati koordinirani timski pristup nadležnih tijela i organizacija civilnog društva u pristupu i ostvarivanju prava žrtvama trgovanja ljudima, Aktivnost: 3. Kontinuirano osiguravanje potrebnih zdravstvenih pregleda žrtvama trgovanja ljudima - Nacionalni plan... od 2018. do 2021. godine, op. cit. u bilj. 1, str. 18. 
Ako uspije pobjeći, žrtva trgovanja ljudima sklonija je prvo zatražiti pomoć od nevladinih organizacija ili neke zdravstvene ustanove nego od policije. ${ }^{45} \check{Z}_{\text {rtve }}$ trgovanja ljudima pate od izrazito teških oblika fizičkog i psihičkog nasilja, stoga postoji veća vjerojatnost da će najprije doći u kontakt $s$ nekim zdravstvenim djelatnikom zbog svojih ozljeda ili drugih zdravstvenih problema. ${ }^{46}$ Zdravstveni problemi koji se pojavljuju kod žrtava trgovanja ljudima uključuju deprivaciju hrane i sna, ekstreman stres, spolno prenosive bolesti, posljedice višestrukih prisilnih ili nesigurno izvedenih pobačaja, ovisnost o drogama (često kao način na koji eksploatator održava svoj nadzor nad žrtvom), fizičko zlostavljanje i mučenje (primjerice, slomljene kosti, gubitak zuba, opekotine od cigareta) te psihičko zlostavljanje koje rezultira posttraumatskim stresnim poremećajem, depresijom i suicidalnošću. ${ }^{47}$ Zbog toga zdravstveni djelatnici mogu imati iznimno važnu ulogu u suzbijanju trgovanja ljudima, jer je riječ o stručnim osobama koje su u mogućnosti da dođu u kontakt sa žrtvama trgovanja, čak i dok se one još uvijek nalaze u zatočeništvu. U tom smislu zdravstveni djelatnici imaju jedinstvenu priliku identificirati žrtvu i intervenirati dok je ona još uvijek pod nadzorom osobe koja ju je zarobila. ${ }^{48}$ Iz tog razloga potrebno je organizirati treninge i izraditi priručnike za zdravstvene djelatnike s ciljem njihova osposobljavanja za identificiranje potencijalnih žrtava trgovanja ljudima. ${ }^{49}$ Pritom se mogu predvidjeti metode podučavanja na daljinu (e-učenje) koje mogu omogućiti veću obuhvaćenost polaznika. Također bi bilo potrebno uspostaviti određeni protokol za postupanje kako bi se žrtva premjestila na neko sigurno mjesto i zaštitila od svojeg eksploatatora.

Druga kategorija stručnih djelatnika s kojima žrtve mogu doći u kontakt jesu djelatnici koji rade na različitim poslovima u okviru kaznenog pravosuđa. Naime, istraživanja provedena u Ujedinjenom Kraljevstvu, Irskoj, Češkoj i Nizozemskoj 2013. i 2014. godine u okviru projekta Response Against Criminal Exploitation (RACE) in Europe pokazala su propuste u identifikaciji žrtava trgovanja ljudima koje se iskorištavaju radi činjenja kaznenih djela, zbog čega se prema njima postupalo kao prema počiniteljima kažnjivih djela, a ne kao prema

45 Moossy, R., Sex Trafficking: Identifying Cases and Victims, NIJ Journal, br. 262, ožujak 2009., https://www.nij.gov/journals/Pages/archive.aspx (17. kolovoza 2018.).

46 Helton, op. cit. u bilj. 42, str. 450.

47 Vidi Dovydaitis, T., Human Trafficking: The Role of the Health Care Provider, Journal of Midwifery \& Women's Health, vol. 55, br. 5, 2010., str. $462-467$.

48 Helton, op. cit. u bilj. 42, str. 453.

49 Vidi, primjerice, National Human Trafficking Hotline, Identifying Victims of Human Trafficking - What to Look for During a Medical Exam/Consultation, https://humantraffickinghotline.org/resources/what-look-healthcare-setting (17. kolovoza 2018.). 
žrtvama. ${ }^{50}$ Kao rezultat takvog propusta, žrtve ne mogu ostvarivati svoja prava koja im kao žrtvama trgovanja ljudima pripadaju te su izložene sekundarnoj viktimizaciji od strane institucija, što smanjuje mogućnost da će nadležnim tijelima pomagati u daljnjoj istrazi, pa njihovi eksploatatori mogu proći nekažnjeno. Kako bi se izbjegao strah žrtava od progona i tako doprinijelo njihovoj uspješnoj identifikaciji te progonu počinitelja trgovanja ljudima, relevantni međunarodni ugovori i direktiva EU-a propisuju tzv. klauzulu nekažnjivosti. ${ }^{51}$ Svrha je te klauzule izbjegavanje pokretanja postupaka odnosno nekažnjavanje žrtava trgovanja ljudima i kada su one bile uključene u nezakonite aktivnosti, no njezina provedba izaziva niz praktičnih i teorijskih problema, a osim toga podrazumijeva prethodnu uspješnu identifikaciju žrtve. ${ }^{52}$

Villacampa i Torres odredile su nekoliko faktora koji negativno utječu na identifikaciju žrtava koje se iskorištavaju radi sudjelovanja u kriminalnim aktivnostima. ${ }^{53}$ Prvi faktor je nedostatak znanja stručnih djelatnika o tom obliku trgovanja ljudima. Policijske istrage uglavnom se provode u okviru velikih operacija protiv organiziranog kriminaliteta, što za posljedicu ima da se izolirani slučajevi spolnog iskorištavanja ili iskorištavanja radi počinjenja kaznenih djela, koji ne ispunjavaju kriterije da se mogu smatrati organiziranim kriminalitetom, ne identificiraju kao slučajevi trgovanja ljudima. ${ }^{54}$ Stereotipovi o žrtvama trgovanja su drugi faktor. Uvriježeno je mišljenje da su žrtve prisiljene na prostituciju isključivo žene, i to strankinje bez dokumenata. Takvi stereotipovi često mogu dovesti do propusta da se neka osoba identificira kao žrtva ako se ne poklapa s predodžbom o tome kako bi žrtva trebala izgledati. ${ }^{55}$ Treći problem odnosi se na nadležnost za identifikaciju žrtve. Ako je došlo do propusta da se na samom početku postupka neka osoba identificira kao žrtva, djelatnici koji poslije dolaze

50 Anti-Slavery International, Trafficking for Forced Criminal Activities and Begging in Europe, Exploratory Study and Good Practice Examples, September 2014, http://www. antislavery.org/wp-content/uploads/2017/01/trafficking_for_forced_criminal_activities_and_begging_in_europe.pdf (17. kolovoza 2018.).

51 Vidi članak 26. Konvencije Vijeća Europe o suzbijanju trgovanja ljudima te članak 8. Direktive 2011/36/EU.

52 Više o ovoj problematici vidi Munivrana Vajda, M.; Dragičević Prtenjača, M.; Maršavelski, A., Nekažnjavanje žrtava trgovanja ljudima u Hrvatskoj - pravni standard kao fikcija ili stvarnost, Zbornik radova Pravnog fakulteta u Splitu, vol. 53, br. 4, 2016. , str. $991-1009$.

53 Villacampa, C.; Torres, N., Human Trafficking for Criminal Exploitation: The Failure to Identify Victims, European Journal on Criminal Policy and Research, vol. 23, br. 3, 2017., str. $400-405$.

54 Ibid., str. 401.

55 Ibid. 
u doticaj s njome možda neće biti skloni razmotriti postoji li takva mogućnost. ${ }^{56}$ Idući faktor su poteškoće u provođenju razgovora sa žrtvom, osobito u slučaju ako je uhićena, kao i ignoriranje traume koju je žrtva pretrpjela, zbog čega njezin iskaz može biti nekonzistentan, fragmentiran, bez dosljednog kronološkog slijeda, a to može dovesti do toga da se isključi mogućnost dodjeljivanja statusa žrtve osobi koja to zapravo jest i koja bi trebala biti zaštićena. ${ }^{57}$ Smatra se da se postupak identificiranja žrtve ne može svesti samo na provođenje razgovora, nego mu se treba pristupiti kao procesu u kojem je žrtvi potrebno omogućiti da se osjeća sigurnom i opuštenom..$^{58}$ Zadnji faktor koji Villacampa i Torres navode je nedostatak spoznaje same žrtve da jest žrtva trgovanja ljudima, što se ponajprije može dogoditi u situacijama kada su osobe prisiljene činiti kažnjiva djela, pa same sebe doživljavaju kao prijestupnike, a ne kao žrtve. ${ }^{59}$

Kao jedno od mogućih rješenja problema vezanih uz identifikaciju žrtve koja se iskorištava radi sudjelovanja u kriminalnim aktivnostima Villacampa i Torres predlažu širenje obuke na djelatnike koji rade na poslovima u okviru kaznenog pravosuđa. ${ }^{60} \mathrm{U}$ tom se smislu ni Nacionalni plan za suzbijanje trgovanja ljudima ne bi trebao ograničavati samo na edukaciju policijskih službenika linije rada organiziranog kriminaliteta koji se bave suzbijanjem trgovanja ljudima i granične policijske službenike te zaposlenike Odjela za podršku žrtvama i svjedocima ${ }^{61}$, već bi u programima osposobljavanja za identificiranje potencijalnih žrtava trgovanja ljudima trebao izričito predvidjeti i uključiti i druge policijske službenike i djelatnike Ministarstva pravosuđa koji bi mogli doći u doticaj sa žrtvama koje se iskorištavaju za kriminalne aktivnosti, a nisu odmah prepoznate kao takve. Međutim, iz Izvješća o provedbi Nacionalnog plana za 2015. godinu vidljivo je da pojedine policijske uprave posebnu pozornost posvećuju edukaciji svojih policijskih službenika na temu trgovanja ljudima ${ }^{62}$, što je vrijedno pohvale te

56 Ibid., str. 402.

57 Ibid., str. 402 - 404. Na to također upozorava i ESLJP u predmetu S. M. protiv Hrvatske, op. cit. u bilj. 27, par. 80 .

58 Ibid., str. $402-403$.

59 Ibid., str. 405.

60 Ibid., str. 406.

${ }^{61}$ Vidi Cilj: 1. Nastaviti obrazovanje ciljanih skupina o trgovanju ljudima na nacionalnoj i međunarodnoj razini, Mjere 1. i 4. - Nacionalni plan... od 2018. do 2021. godine, op. cit. u bilj. 1, str. $24-26$.

62 Vlada Republike Hrvatske, Ured za ljudska prava i prava nacionalnih manjina, Izvješce o provedbi Nacionalnog plana za suzbijanje trgovanja ljudima za razdoblje od 2012. do 2015. godine za 2015. godinu, Zagreb, 2016., str. 33, https://ljudskaprava.gov.hr/ ljudska-prava/suzbijanje-trgovanja-ljudima/599 (17. kolovoza 2018.). 
nadilazi aktivnosti koje su bile predviđene samim Nacionalnim planom 2012. - 2015., a nisu ni bile dovoljno specificirane. Naime, Nacionalni plan 2012. 2015., pa tako i Nacionalni plan 2018. - 2021., predviđa održavanje seminara za policijske službenike u okviru Policijske akademije, a ne u okviru pojedinih policijskih uprava. ${ }^{63}$

\subsection{Prevencija trgovanja ljudima u okviru europske migrantske krize i potreba provedbe specifičnih aktivnosti usmjerenih na zaštitu djece}

Trenutačna migrantska kriza u Europi jedna je od najvećih humanitarnih kriza u današnjem svijetu. Među migrantima djeca su posebno prepoznata kao ranjiva skupina u riziku da postanu žrtve trgovanja ljudima, osobito kada su odvojena od svojih roditelja ili srodnika ili su bez ikakve pratnje. ${ }^{64} \mathrm{U}$ svojem izvješću iz svibnja 2017. UNICEF je upozorio na to da je broj djece izbjeglica i migranata koji putuju bez pratnje dosegnuo rekordno visoku stopu na svjetskoj razini (300.000 djece bez pratnje i djece odvojene od obitelji zabilježeno je u 80-ak država tijekom 2015. i 2016. godine), a u odnosu na stanje 2010. godine taj je broj gotovo pet puta veći. ${ }^{65}$ Prema podacima Europske migracijske mreže između 2014. i 2017. godine 219.575 maloljetnika bez pratnje došlo je u Europsku uniju i Norvešku tražiti azil. ${ }^{66} \mathrm{U}$ istom razdoblju još je barem 48.591 maloljetnik došao bez pratnje iz drugih razloga (nisu zatražili azil), ali broj djece koja su izvan sustava azila uglavnom je nepoznat. ${ }^{67}$ Obertová i Cattaneo navode podatke o 10.000 migrantske djece koja su nestala u Europi, od kojih mnoga

63 Vidi Mjera 5. Nastaviti obrađivanje teme suzbijanje trgovanja ljudima u okviru redovitog programa obrazovanja koje provodi Pravosudna akademija i Policijska akademija - Nacionalni plan... od 2012. do 2015. godine, op. cit. u bilj. 8, str. 18, i Nacionalni plan... od 2018. do 2021. godine, op. cit. u bilj. 1, str. $26-27$.

Obertová, Z.; Cattaneo, C., Child Trafficking and the European Migration Crisis: The Role of Forensic Practitioners, Forensic Science International, vol. 282, 2018., str. 48.

United Nations Children's Fund (UNICEF), A Child is a Child: Protecting Children on the Move From Violence, Abuse and Exploitation, May 2017, str. 6, https://data.unicef. org/resources/child-child-protecting-children-move-violence-abuse-exploitation/ (17. kolovoza 2018.).

66 European Commission, Approaches to Unaccompanied Minors Following Status Determination in the EU plus Norway: Synthesis Report for the EMN Study, July 2018, str. 12, https://ec.europa.eu/home-affairs/sites/homeaffairs/files/00_eu_synthesis_report_ unaccompanied_minors_2017_en.pdf (17. kolovoza 2018.).

Ibid., str. 5. 
nestanu iz prihvatnih centara, a da ih nadležna tijela nisu ni registrirala. ${ }^{68} \mathrm{Način}$ postupanja u državama članicama Europske unije je vrlo različit te ponekad takvi slučajevi imaju manji prioritet nego nestanci djece vlastitih državljana ili se nestanci uopće ne istražuju. ${ }^{69}$ Takva djeca smatraju se jako ranjivom te su pod većim rizikom da postanu žrtve trgovanja ljudima. ${ }^{70}$ Osim toga, trgovci ljudima zloupotrebljavaju sustav azila tako da prisiljavaju žrtve da zatraže azil, što omogućava njihovo lakše kretanje u okviru Schengenskog prostora. ${ }^{71}$ Problemi vezani uz migrantsku krizu nisu zaobišli ni Republiku Hrvatsku. U svojem drugom evaluacijskom izvještaju Skupina stručnjaka za suzbijanje trgovanja ljudima Vijeća Europe, poznata pod engleskim akronimom GRETA, upozorila je na povećan broj djece bez pratnje te na zabrinjavajuću pojavu da ta djeca često vrlo brzo nestaju iz prihvatnih centara za tražitelje međunarodne zaštite. Stoga je od hrvatskih vlasti zatražila pojačanje napora na sprječavanju trgovanja djecom, kao i općenito proaktivniji pristup svih relevantnih institucija identifikaciji žrtava trgovanja ljudima, osobito među tražiteljima azila, u prihvatnim centrima za strance te općenito među migrantima. ${ }^{72}$ I Europska komisija prepoznala je važnost zaštite djece u svim fazama migracije u svojoj Komunikaciji "Zaštita djece migranata" iz 2017. godine. ${ }^{73}$ Komunikacija je podijeljena u nekoliko poglavlja, a konkretne preporuke odnose se na brzu i cjelovitu identifikaciju i zaštitu, pružanje odgovarajućeg prihvata, osiguravanje brzog i učinkovitog pristupa postupcima za određivanje statusa i primjenu postupovnih zaštitnih mjera, osiguravanje trajnih rješenja, te horizontalne mjere: poštovanje i jamstva za najbolji interes djeteta i učinkovitija uporaba podataka, istraživanja, osposobljavanja i financijskih sredstava.

68 Obertová, Cattaneo, op. cit. u bilj. 64, str. 47.

69 Ibid., str. $48-49$.

70 European Commission, Study on High-Risk Groups for Trafficking in Human Beings: Executive Summary, 2015., str. 8, https://ec.europa.eu/anti-trafficking/eu-policy/ study-high-risk-groups-trafficking-human-beings_en (17. kolovoza 2018.).

71 Europol, Situation Report: Trafficking in Human Beings in the EU, veljača 2016., str. 12, https://www.europol.europa.eu/publications-documents/trafficking-in-human-beings-in-eu (17. kolovoza 2018.).

72 Group of Experts on Action against Trafficking in Human Being (GRETA), Report Concerning the Implementation of the Council of Europe Convention on Action against Trafficking in Human Beings by Croatia: Second Evaluation Round, published 4 February 2016, točke 64. i 65., str. 15 i točka 94., str. 20, https://www.coe.int/en/web/anti-human-trafficking/croatia (17. kolovoza 2018.).

73 Komunikacija Komisije Europskom parlamentu i Vijeću, Zaštita djece migranata, COM(2017) 211 final, Bruxelles, 12. travnja 2017. 
S obzirom na navedene podatke iz najnovijih istraživanja, upute GRETA-e, kao i dostupnost brojnih preporuka za prevenciju trgovanja djecom migrantima koje predlažu relevantna međunarodna tijela smatramo da je Nacionalni plan 2018. - 2021. propustio predvidjeti mjere i aktivnosti za rješavanje navedenog problema. Jedina predviđena aktivnost koja bi se mogla odnositi na postupke prevencije trgovanja djecom migrantima jest izrada indikatora, smjernica i alata za identifikaciju djece žrtava trgovanja ljudima. Osim toga, Protokol o postupanju prema djeci odvojenoj od roditelja - stranim državljanima, koji je Vlada usvojila u srpnju 2017. (nije objavljen u Narodnim novinama), također je nedostatan za zaštitu djece migranata od trgovaca ljudima jer ne sadržava posebne odredbe o tome, nego u članku 21. upućuje na Nacionalni plan za suzbijanje trgovanja ljudima i njegove protokole. Stoga bi bilo svrsishodno u Nacionalnom planu predvidjeti i druge mjere i aktivnosti koje, primjerice, predlaže Europska komisija u svojoj Komunikaciji "Zaštita djece migranata” iz 2017., a koje bi se na odgovarajući način mogle primijeniti i na sprečavanje trgovanja djecom u kontekstu postojeće europske migrantske krize koja je zahvatila i Hrvatsku.

\subsection{Povratak i reintegracija stranih žrtava trgovanja ljudima i potreba prevencije ponovnog trgovanja ili progona žrtve nakon povratka $u$ zemlju porijekla}

Prema dostupnim podacima većina identificiranih žrtava trgovanja ljudima u Hrvatskoj su hrvatski državljani, a manji broj žrtava dolazi iz drugih država. ${ }^{74}$ Godišnja izvješća Vladina Ureda za ljudska prava i prava nacionalnih manjina o provedbi Nacionalnog plana (2012. - 2015.) pokazuju da su provedeni malobrojni postupci povratka žrtava trgovanja ljudima (u 2012. godini organiziran je povratak za dva rumunjska državljana i jednu državljanku SAD-a, u 2013. godini za jednu osobu srpskog državljanstva i jednu osobu bosansko-hercegovačkog državljanstva, u 2014. godini za tri osobe bosansko-hercegovačkog državljanstva, te u 2015. godini za jednu maloljetnu državljanku Makedonije). Možda je to razlog zašto ni najnoviji Nacionalni plan ne sadržava nijednu mjeru ni aktivnost vezanu uz prevenciju ponovnog trgovanja ili progona žrtve nakon povratka u zemlju podrijetla. Osim toga, moguće je da se Protokol o postupanju pri dobrovoljnom povratku žrtava trgovanja ljudima smatra dovoljnim za ispunjenje obveza što proizlaze iz članka 16. Konvencije Vijeća Europe o suzbijanju trgovanja ljudima

74 Vidi Tabelarni prikaz identificiranih žrtava u: Izvješće o provedbi Nacionalnog plana za suzbijanje trgovanja ljudima za razdoblje od 2012. do 2015. godine za 2015. godinu, op cit. u bilj. 8, str. 8 . 
koji se odnosi na vraćanje žrtava u zemlju podrijetla. ${ }^{75}$ Međutim, u svojem drugom evaluacijskom izvještaju GRETA je zaključila da hrvatska nadležna tijela trebaju poduzeti dodatne korake da zaštite žrtve od ponovne viktimizacije i trgovanja ljudima, a jednako tako da osiguraju poštovanje obveze non-refoulement odnosno zabrane protjerivanja ili vraćanja na područje gdje postoji vjerojatnost da će njihov život ili sloboda bili ugroženi. ${ }^{76}$

Analizom odredaba Protokola o postupanju pri dobrovoljnom povratku žrtava trgovanja ljudima vidljivo je da su njegove odredbe u važnim dijelovima napisane vrlo općenito i da se stoga ne mogu smatrati dostatnima za prevenciju ponovnog trgovanja ili progona žrtve nakon povratka u zemlju podrijetla. Primjerice, $\mathrm{u}$ članku 7., koji se odnosi na procjenu rizika i sigurnosti žrtve, navedeno je samo šest načelnih okolnosti koje se utvrđuju u zemlji povratka ${ }^{77}$, a u članku 10. stavku 1. propisano je da će u organiziranju povratka Ministarstvo unutarnjih poslova te ministarstvo nadležno za poslove socijalne skrbi surađivati s nadležnim državnim tijelima, međunarodnim organizacijama i organizacijama civilnog društva u zemlji povratka bez ikakva konkretiziranja što bi ta suradnja trebala obuhvaćati i kako bi se trebala uspostaviti ili unaprijediti.

S obzirom na dostupnost brojnih smjernica, izvješća, preporuka, studija i sl. koje se odnose na osiguravanje sigurnog povratka i reintegracije žrtava trgovanja ljudima ${ }^{78}$, smatramo da je velik propust što se u Nacionalnom planu

75 U svojem odgovoru na upitnik za evaluaciju provedbe Konvencije o suzbijanju trgovanja ljudima (studeni 2014.) Hrvatska je samo sažeto navela odredbe Protokola. Vidi Reply from Croatia to the Questionnaire for the Evaluation of the Implementation of the Council of Europe Convention on Action against Trafficking in Human Beings by the Parties: Second Evaluation Round, published 24 February 2015, str. 37 - 38, https://www.coe. int/en/web/anti-human-trafficking/croatia (17. kolovoza 2018.).

76 GRETA, op. cit. u bilj. 72, točka 142., str. 29.

77 Okolnosti su: mogućnost i sigurnost povratka u zemlju u koju se žrtva želi vratiti, naziv organizacije odnosno ime, prezime i svojstvo osobe koja će prihvatiti žrtvu, obiteljske i socijalne okolnosti žrtve, mogućnost sigurnog smještaja (sklonište ili alternativni smještaj), okolnosti koje se odnose na kazneno djelo i počinitelja, po potrebi i ostale okolnosti važne za povratak žrtve.

78 Vidi, primjerice, International Organization for Migration (IOM), Enhancing the Safety and Sustainability of the Return and Reintegration of Victims of Trafficking (2015), https://publications.iom.int/books/enhancing-safety-and-sustainability-return-and-reintegration-victims-trafficking (17. kolovoza 2018.); International Organization for Migration (IOM), The Causes and Consequences of Re-trafficking: Evidence from the IOM Human Trafficking Database (2010), https://publications.iom.int/system/ files/pdf/causes_of_retrafficking.pdf (17. kolovoza 2018.); United Nations Office on Drugs and Crime (UNODC), Model Law against Trafficking in Persons (2009), https:// www.unodc.org/documents/human-trafficking/UNODC_Model_Law_on_Traffic- 
nisu predvidjele mjere i aktivnosti u svrhu sprečavanja ponovne viktimizacije žrtve. Uključivanjem preporuka najbolje prakse u Nacionalni plan omogućila bi se bolja zaštita žrtava u slučaju njihova povratka te bi se u većoj mjeri spriječio povratak onih za koje postoji vjerojatnost progona ili da će ponovno postati žrtve trgovanja. Time bi Hrvatska ispunila obvezu iz članka 9. stavka 1. b) Protokola iz Palerma, koji nalaže uspostavu sveobuhvatne politike, programa i drugih mjera za zaštitu žrtava trgovanja osoba od ponovnog postajanja žrtvom.

\section{ZAKLJUČAK}

Ovaj rad pokazuje kako, unatoč napretku koji je postignut u posljednjih petnaestak godina u Republici Hrvatskoj na području suzbijanja trgovanja ljudima, još uvijek predstoje značajni koraci kako bi se postojeći pravni i institucionalni okvir uskladio sa zahtjevima vladavine prava i načela zakonitosti te uspješno primijenio u praksi u smislu rane identifikacije žrtava, prevencije trgovanja ljudima i ponovne viktimizacije te učinkovitog progona počinitelja. U Republici Hrvatskoj ne postoji zakon koji bi cjelovito i sveobuhvatno regulirao materiju trgovanja ljudima, već je materija razasuta po brojnim zakonima, a zakonom neregulirana pitanja razrađena su Vladinim aktima - protokolima. Takvo pravno uređenje problematično je iz više aspekata. Prije svega, iako su pisani normativnim stilom $\mathrm{u}$ formi članaka, protokoli formalnopravno nisu propisi, pa ne mogu proizvoditi prava i obveze za treće osobe. Osim toga, pojedine odredbe protokola odstupaju od zakonskih rješenja ili ih dopunjuju ${ }^{79}$, a takav učinak nije moguće proizvesti ni podzakonskim propisima, a pogotovo ne zaključcima i internim napucima koji po svojem pravnom karakteru uopće nisu propis. Konačno, protokoli iz područja trgovanja ljudima nisu objavljeni u Narodnim novinama, zbog čega je upitna upoznatost adresata s njima, a ne postoji ni zakonska ovlast za njihovo donošenje. Zbog svega navedenog kao najbolje rješenje vidimo donošenje sveobuhvatnog zakona koji bi cjelovito uredio važna pitanja iz područja trgovanja ljudima, osim kaznenopravne materije, za koju predlažemo da se zadrži u Kaznenom zakonu i Zakonu o kaznenom

king_in_Persons.pdf (17. kolovoza 2018.); Save the Children UK, United Nations Inter-Agency Project on Human Trafficking (UNIAP) and International Organization for Migration (IOM), Training Manual for Combating Trafficking in Women and Children (2001), https://www.unicef.org/easterncaribbean/spmapping/Implementation/ CP/Global/trafficking_manual_2002.pdf (17. kolovoza 2018.). Vidi također: Schloenhardt, A.; Loong, M., Return and Reintegration of Human Trafficking Victims from Australia, International Journal of Refugee Law, vol. 23, br. 2, 2011., str. 143 - 173.

Vidi supra poglavlje 2.1. 
postupku. Ako pak zakonodavac odluči zadržati postojeći pristup, svakako bi trebalo u postojeće zakone koji parcijalno uređuju i materiju trgovanja ljudima izričito unijeti ovlast Vlade za donošenje podzakonskih propisa koji bi zamijenili dosadašnje pravno neobvezujuće protokole ili pak izmijeniti njihov sadržaj u skladu s činjenicom da nije riječ o propisima.

S kaznenopravnog aspekta materija trgovanja ljudima adekvatno je normirana Kaznenim zakonom i Zakonom o kaznenom postupku, no kao što posljednja presuda Europskog suda za ljudska prava zorno pokazuje, problemi se javljaju pri praktičnoj primjeni. Iako je u predmetu S. M. žrtva uspješno identificirana te joj je ponuđena zaštita, to čini tek jedan korak u lancu učinkovite borbe protiv trgovanja ljudima. Kao što i strategija Europske unije protiv trgovanja ljudima pokazuje, potreban je sveobuhvatan pristup u smislu ne samo prevencije i zaštite žrtava nego i u smislu učinkovitog progona počinitelja ${ }^{80}$, koji je u ovom predmetu izostao. Ta presuda pokazuje potrebu i za edukacijom sudaca, koji ne samo da moraju biti upoznati s prirodom i indikatorima relevantnih kaznenih djela $^{81}$ već moraju moći razumjeti i posebne potrebe i iskustvo žrtava koje se može reflektirati i na njihov svjedočki iskaz. ${ }^{82}$

$\mathrm{Na}$ potrebu za edukacijom drugih struka, posebice policije i zdravstvenih djelatnika, upućujemo u posljednjem dijelu rada. Nažalost, novi Nacionalni plan nije predvidio dostatne mjere i aktivnosti na tom polju, iako bi one sasvim sigurno mogle pridonijeti ranoj detekciji žrtava trgovanja ljudima, koje, kao što je vidljivo i iz predmeta S. M. protiv Hrvatske, ne moraju nužno biti vezane uz prekogranični organizirani kriminal. Stoga bi trebalo educirati širi krug policijskih službenika koji u svakodnevnom radu mogu doći u doticaj sa žrtvama trgovanja ljudima, kao što su, primjerice, osobe iskorištavane za prostituciju i druge kriminalne aktivnosti. Osim toga, edukacijskim programima trebalo bi obuhvatiti i zdravstvene djelatnike, koji, iskustva pokazuju, mogu ostvariti prvi (i jedini) kontakt sa žrtvama trgovanja ljudima. U posljednjem se dijelu rada upućuje i na druge propuste Nacionalnog plana da predvidi potrebne aktivnosti i mjere s ciljem zaštite najosjetljivije skupine žrtava - djece te bolje reintegracije žrtava i prevencije ponovnog trgovanja ljudima.

80 The EU Strategy towards the Eradication of Trafficking in Human Beings, op.cit. u bilj. 41.

81 O pogrešnim kvalifikacijama i neprepoznatom trgovanju djecom vidi Munivrana Vajda, M., Komentar sudske prakse o trgovanju ljudima, Hrvatski ljetopis za kaznene znanosti i praksu, vol. 24, br. 2, 2017., str. $723-728$.

82 S. M. protiv Hrvatske, op. cit. u bilj. 27, par. 80. 


\section{LITERATURA}

Anti-Slavery International, Trafficking for Forced Criminal Activities and Begging in Europe, Exploratory Study and Good Practice Examples, September 2014, http:// www.antislavery.org/wp-content/uploads/2017/01/trafficking_for_forced_criminal_activities_and_begging_in_europe.pdf (17. kolovoza 2018.)

Borković, I., Upravno pravo, Informator, Zagreb, 1997.

Derenčinović, D., Nisu na prodaju - o pravima žrtava trgovanja ljudima nakon presude Europskog suda za ljudska prava u predmetu Rantsev protiv Cipra i Rusije, Godišnjak Akademije pravnih znanosti Hrvatske, vol. 1, br. 1, 2010., str. $53-57$

Dovydaitis, T., Human Trafficking: The Role of the Health Care Provider, Journal of Midwifery \& Women's Health, vol. 55, br. 5, 2010., str. $462-467$

European Commission, Approaches to Unaccompanied Minors Following Status Determination in the EU plus Norway: Synthesis Report for the EMN Study, July 2018, https://ec.europa.eu/home-affairs/sites/homeaffairs/files/00_eu_synthesis_report_unaccompanied_minors_2017_en.pdf (17. kolovoza 2018.)

European Commission, Study on High-Risk Groups for Trafficking in Human Beings: Executive Summary, 2015., https://ec.europa.eu/anti-trafficking/eu-policy/ study-high-risk-groups-trafficking-human-beings_en (17. kolovoza 2018.)

European Commission, The EU Strategy towards the Eradication of Trafficking in Human Beings 2012-2016, COM(2012) 286 final, Brussels, 19. lipnja 2012.

Europol, Situation Report: Trafficking in Human Beings in the EU, veljača 2016., https://www.europol.europa.eu/publications-documents/trafficking-in-human-beings-in-eu (17. kolovoza 2018.)

Group of Experts on Action against Trafficking in Human Being (GRETA), Report Concerning the Implementation of the Council of Europe Convention on Action against Trafficking in Human Beings by Croatia: Second Evaluation Round, published 4 February 2016, https://www.coe.int/en/web/anti-human-trafficking/ croatia (17. kolovoza 2018.)

Helton, M., Human Trafficking: How a Joint Task Force Between Health Care Providers and Law Enforcement Can Assist with Identifying Victims and Prosecuting Traffickers, Health Matrix, vol. 26, br. 1, 2016., str. 433 - 473

Herceg Pakšić, B.; Jukić, M., Primjena konvencijskog prava u području zabrane ropstva i prisilnog rada: europski standardi i hrvatska postignuća, Hrvatski ljetopis za kaznene znanosti i praksu, vol. 23, br. 2, 2016., str. 281 - 310

International Organization for Migration (IOM), Enhancing the Safety and Sustainability of the Return and Reintegration of Victims of Trafficking, 2015., 
https://publications.iom.int/books/enhancing-safety-and-sustainability-return-and-reintegration-victims-trafficking (17. kolovoza 2018.)

International Organization for Migration (IOM), The Causes and Consequences of Re-trafficking: Evidence from the IOM Human Trafficking Database, 2010., https://publications.iom.int/system/files/pdf/causes_of_retrafficking.pdf (17. kolovoza 2018.)

Ivančević, V., Institucije upravnog prava, Pravni fakultet u Zagrebu, Zagreb, 1983.

Komunikacija Komisije Europskom parlamentu i Vijeću, Zaštita djece migranata, $\operatorname{COM}(2017) 211$ final, Bruxelles, 12. travnja 2017.

Moossy, R., Sex Trafficking: Identifying Cases and Victims, NIJ Journal, br. 262, ožujak 2009., https://www.nij.gov/journals/Pages/archive.aspx (17. kolovoza 2018.)

Munivrana Vajda, M.; Dragičević Prtenjača, M.; Maršavelski A., Nekažnjavanje žrtava trgovanja ljudima u Hrvatskoj - pravni standard kao fikcija ili stvarnost, Zbornik radova Pravnog fakulteta u Splitu, vol. 53, br. 4, 2016., str. 991 - 1009

Munivrana Vajda, M., Komentar sudske prakse o trgovanju ljudima, Hrvatski ljetopis za kaznene znanosti i praksu, vol. 24, br. 2, 2017., str. 723 - 728

National Human Trafficking Hotline, Identifying Victims of Human Trafficking - What to Look for During a Medical Exam/Consultation, https://humantraffickinghotline. org/resources/what-look-healthcare-setting (pristup: 17. kolovoza 2018.)

Obertová, Z.; Cattaneo, C., Child Trafficking and the European Migration Crisis: The Role of Forensic Practitioners, Forensic Science International, vol. 282, 2018., str. $46-59$

Reply from Croatia to the Questionnaire for the Evaluation of the Implementation of the Council of Europe Convention on Action against Trafficking in Human Beings by the Parties: Second Evaluation Round, published 24 February 2015, https://www. coe.int/en/web/anti-human-trafficking/croatia (17. kolovoza 2018.)

Save the Children UK, United Nations Inter-Agency Project on Human Trafficking (UNIAP) and International Organization for Migration (IOM), Training Manual for Combating Trafficking in Women and Children, 2001., https://www. unicef.org/easterncaribbean/spmapping/Implementation/CP/Global/trafficking_manual_2002.pdf (17. kolovoza 2018.)

Schloenhardt, A.; Loong, M., Return and Reintegration of Human Trafficking Victims from Australia, International Journal of Refugee Law, vol. 23, br. 2, 2011., str. $143-173$

United Nations Children's Fund (UNICEF), A Child is a Child: Protecting Children on the Move From Violence, Abuse and Exploitation, May 2017, https://data.unicef. org/resources/child-child-protecting-children-move-violence-abuse-exploitation/ (17. kolovoza 2018.) 
United Nations Office on Drugs and Crime (UNODC), Model Law against Trafficking in Persons, 2009., https://www.unodc.org/documents/human-trafficking/ UNODC_Model_Law_on_Trafficking_in_Persons.pdf (17. kolovoza 2018.)

Villacampa, C.; Torres, N., Human Trafficking for Criminal Exploitation: The Failure to Identify Victims, European Journal on Criminal Policy and Research, vol. 23, br. 3, 2017., str. $393-408$

Vlada Republike Hrvatske, Ured za ljudska prava i prava nacionalnih manjina, Izvješce o provedbi Nacionalnog plana za suzbijanje trgovanja ljudima za razdoblje od 2012. do 2015. godine za 2015. godinu, Zagreb, 2016., https://ludskaprava. gov.hr/ljudska-prava/suzbijanje-trgovanja-ljudima/599 (17. kolovoza 2018.)

\section{PROPISI I DRUGI AKTI}

Kazneni zakon, Narodne novine, br. 110/1997, 27/1998, 50/2000, 129/2000, 51/2001, 111/2003, 190/2003, 105/2004, 84/2005, 71/2006, 110/2007, $152 / 2008,57 / 2011$ i $143 / 2012$

Kazneni zakon, Narodne novine, br. 125/2011, 144/2012, 56/2015, 61/2015 i $101 / 2017$

Konvencija za zaštitu ljudskih prava i temeljnih sloboda, Narodne novine, Međunarodni ugovori, br. 18/1997, 6/1999 - pročišćeni tekst, 8/1999 - ispravak, $14 / 2002$ i $1 / 2006$

Odluka o osnivanju Nacionalnog odbora za suzbijanje trgovanja ljudima, Narodne novine, br. 54/2002, 4l/2004, 122/2009 i 119/2010

Odluka o osnivanju Nacionalnog odbora za suzbijanje trgovanja ljudima, Narodne novine, br. 42/2012, 49/2015 i 30/2018

Ustav Republike Hrvatske, Narodne novine, br. 56/1990, 135/1997, 113/2000, 28/2001, 76/2010 i 5/2014

Vlada Republike Hrvatske, Nacionalni odbor za suzbijanje trgovanja ljudima, Nacionalni plan za suzbijanje trgovanja ljudima za razdoblje od 2012. - 2015., Zagreb, 2012., https://ljudskaprava.gov.hr/ljudska-prava/suzbijanje-trgovanja-ljudima/599

Vlada Republike Hrvatske, Nacionalni odbor za suzbijanje trgovanja ljudima, Nacionalni plan za suzbijanje trgovanja ljudima za razdoblje od 2018. do 2021. godine, Zagreb, 2018., https://ludskaprava.gov.hr/ljudska-prava/suzbijanje-trgovanja-ljudima/599

Vlada Republike Hrvatske, Protokol o integraciji/reintegraciji žrtava trgovanja ljudima, 2017., https://judskaprava.gov.hr/ljudska-prava/suzbijanje-trgovanja-ljudima/599 
Vlada Republike Hrvatske, Protokol o postupanju pri dobrovoljnom povratku žrtava trgovanja ljudima, 2017., https://judskaprava.gov.hr/ljudska-prava/ suzbijanje-trgovanja-ljudima/599

Vlada Republike Hrvatske, Protokol za identifikaciju, pomoć i zaštitu trgovanja ljudima, 2017., https://judskaprava.gov.hr/ljudska-prava/suzbijanje-trgovanja-ljudima/599

Zakon o općem upravnom postupku, Narodne novine, br. 47/2009

Zakon o potvrđivanju Konvencije Ujedinjenih naroda protiv transnacionalnoga organiziranog kriminaliteta, Protokola za sprječavanje, suzbijanje i kažnjavanje krijumčarenja ljudi, posebice žena i djece te Protokola protiv krijumčarenja migranata kopnom, morem i zrakom, kojima se dopunjuje Konvencija Ujedinjenih naroda protiv transnacionalnoga organiziranog kriminaliteta, Narodne novine, Međunarodni ugovori, br. 14/2002 i 11/2004 - ispravak

Zakon o potvrđivanju Konvencije Vijeća Europe o suzbijanju trgovanja ljudima, Narodne novine, Međunarodni ugovori, br. 7/2007

Zakon o Vladi Republike Hrvatske, Narodne novine, br. 101/1998, 15/2000 i $117 / 2001$

Zakon o Vladi Republike Hrvatske, Narodne novine, br. 150/2011, 119/2014 i $93 / 2016$

Zakon o sustavu državne uprave, Narodne novine, br. 150/2011, 12/2013, 93/2016 i 104/2016

Zakon o strancima, Narodne novine, br. 130/2011, 74/2013, 69/2017 i 46/2018

\section{PRAKSA EUROPSKOG SUDA ZA LJUDSKA PRAVA}

Presuda od 19. srpnja 2018., S. M. protiv Hrvatske, zahtjev br. 60561/14

Presuda od 7. siječnja 2010., Rantsev protiv Cipra, zahtjev br. 25965/04

\section{PRAKSA USTAVNOG SUDA REPUBLIKE HRVATSKE}

Odluka od 15. travnja 2014., U-II-2168/2013 i dr.

Rješenje od 19. prosinca 2013., U-II-3209/2013 i U-II-4311/2013 
Summary

Lana Ofak*

Maja Munivrana Vajda **

\section{RECOMMENDATIONS FOR IMPROVING THE CROATIAN LEGAL FRAMEWORK AND MEASURES FOR SUPPRESSION AND PREVENTION OF TRAFFICKING IN HUMAN BEINGS}

In this paper the authors analyse the existing legal and institutional framework for combatting human trafficking in the Republic of Croatia. Although the Republic of Croatia started building a legal system for the suppression of trafficking in human beings already in 2002, this matter has still not received adequate attention from the legislator, which is why many issues are left to the executive branch and its protocols. The authors criticize this regulatory approach and propose several possible solutions. They further analyse the recent judgement of the European court of Human Rights in the case of S.M. versus Croatia, which clearly illustrates the problems associated with the prosecution of perpetrators of human trafficking. The last part of the paper studies the new National plan for the suppression of trafficking in human beings and warns of its manifest omission to propose efficient measures and activities for victim identification, prevention of trafficking in migrant children, and protection of victims from re-trafficking or persecution upon return to their country of origin.

Key words: human trafficking, National plan for the suppression of trafficking in human beings, protocols, European Court of Human Rights, victims of human trafficking

\footnotetext{
Lana Ofak, Ph. D., Associate Professor, Faculty of Law, University of Zagreb, Trg Republike Hrvatske 14, Zagreb; lofak@pravo.hr;

ORCID ID: orcid.org/0000-0001-7585-6370

** Maja Munivrana Vajda, Ph. D., Associate Professor, Faculty of Law, University of Zagreb, Trg Republike Hrvatske 14, Zagreb; mmunivra@pravo.hr;

ORCID ID: orcid.org/0000-0001-9496-6102
} 
